\title{
OA16.04. Women's sources of information for CAM use during pregnancy
}

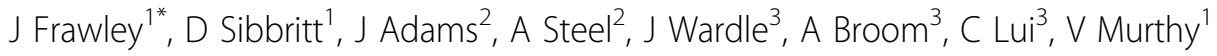 \\ From International Research Congress on Integrative Medicine and Health 2012 \\ Portland, Oregon, USA. 15-18 May 2012
}

\section{Purpose}

It is well known that women of reproductive age are high consumers of complementary and alternative medicine (CAM) with emerging research highlighting the use of high amounts of CAM in pregnancy. Substantial data exists about the information sources women use for utilising complementary medicines and treatments generally, however little is known about the sources of information used in pregnancy. Various authors have raised concerns about aspects of safety in relation to consuming CAM in pregnancy and it is important to elucidate and understand the resources that women are using to gather this information. The objective of our study was to examine women's information sources when deciding to use CAM in pregnancy.

\section{Methods}

We analysed data from the Australian Longitudinal Study of Women's Health (ALSWH). The ALSWH is a longitudinal population-based survey which examines the health of a representative sample of over 40,000 Australian women in 3 age groupings. This study has analysed data from a sub-study of 1740 women from the young cohort. These data were supplemented by a review of the literature from the last 10 years.

\section{Results}

Fifty-three percent of women used herbal medicine in pregnancy, whilst only $7.2 \%$ visited a herbalist or naturopath; $89.1 \%$ consumed vitamins and minerals of which $43.7 \%$ self-prescribed these supplements. Women were found to use a variety of sources for information on CAM during pregnancy, namely obstetricians $(25.8 \%)$ and general practitioners (14.4\%), followed by alternative health practitioners $(14.3 \%)$. Overall, the result for non-

${ }^{1}$ University of Newcastle, Katoomba, NSW, Australia

Full list of author information is available at the end of the article professional sources of information (friends, family, internet, magazines etc.) always or sometimes was $61.6 \%$ as compared to $61.9 \%$ for professional sources.

\section{Conclusion}

Women are using a variety of sources of information about CAM in pregnancy. Many of these are of questionable quality. Health care professionals need to be aware of this and check that women are only consuming CAM products that are safe during pregnancy.

\section{Author details}

${ }^{1}$ University of Newcastle, Katoomba, NSW, Australia. ${ }^{2}$ University of Technology Sydney, Sydney, Australia. ${ }^{3}$ University of Queensland, Brisbane, Australia.

Published: 12 June 2012

doi:10.1186/1472-6882-12-S1-065

Cite this article as: Frawley et al:: OA16.04. Women's sources of

information for CAM use during pregnancy. BMC Complementary and Alternative Medicine 2012 12(Suppl 1):O65.

Submit your next manuscript to BioMed Central and take full advantage of:

- Convenient online submission

- Thorough peer review

- No space constraints or color figure charges

- Immediate publication on acceptance

- Inclusion in PubMed, CAS, Scopus and Google Scholar

- Research which is freely available for redistribution

\section{() Biomed Central}

(c) 2012 Frawley et al; licensee BioMed Central Ltd. This is an Open Access article distributed under the terms of the Creative Commons Attribution License (http://creativecommons.org/licenses/by/2.0), which permits unrestricted use, distribution, and reproduction in any medium, provided the original work is properly cited. 